\title{
Ecology and application of haloalkaliphilic anaerobic microbial communities
}

\author{
João A.B. Sousa ${ }^{1,2}$ • Dimitry Y. Sorokin ${ }^{3,4}$ • Martijn F.M. Bijmans ${ }^{2}$ • \\ Caroline M. Plugge ${ }^{1,2}$ • Alfons J.M. Stams ${ }^{1,5}$
}

Received: 18 May 2015 /Revised: 9 August 2015 / Accepted: 13 August 2015 /Published online: 10 September 2015

(C) The Author(s) 2015. This article is published with open access at Springerlink.com

\begin{abstract}
Haloalkaliphilic microorganisms that grow optimally at high-pH and high-salinity conditions can be found in natural environments such as soda lakes. These globally spread lakes harbour interesting anaerobic microorganisms that have the potential of being applied in existing technologies or create new opportunities. In this review, we discuss the potential application of haloalkaliphilic anaerobic microbial communities in the fermentation of lignocellulosic feedstocks material subjected to an alkaline pre-treatment, methane production and sulfur removal technology. Also, the general advantages of operation at haloalkaline conditions, such as low volatile fatty acid and sulfide toxicity, are addressed. Finally,
\end{abstract}

João A.B. Sousa

joao.sousa@wetsus.nl

Dimitry Y. Sorokin

d.sorokin@tudelft.nl

Martijn F.M. Bijmans

martijn.bijmans@wetsus.nl

Caroline M. Plugge

caroline.plugge@wur.nl

Alfons J.M. Stams

fons.stams@wur.nl

1 Laboratory of Microbiology, Wageningen University, Dreijenplein 10, 6703 HB Wageningen, The Netherlands

2 Wetsus, European Centre of Excellence for Sustainable Water Technology, Oostergoweg 9, 8911 MA Leeuwarden, the Netherlands

3 Winogradsky Institute of Microbiology, Research Centre of Biotechnology, Russian Academy of Sciences, Moscow, Russia

4 Department of Biotechnology, Delft University of Technology, 2628 BC Delft, the Netherlands

5 Department of Biological Engineering, University of Minho, Braga, Portugal an outlook into the main challenges like ammonia toxicity and lack of aggregation is provided.

Keywords Anaerobic - Haloalkaline - Haloalkaliphilic · Fermentation · Lignocellulosic feedstocks · Methane · Sulfidogenesis · Toxicity

\section{Introduction}

The metabolic potential of anaerobic microorganisms has been exploited in a wide range of applications, like volatile fatty acids (VFAs), alcohols, $\mathrm{H}_{2}$ and methane production. However, information about the application of haloalkaliphilic anaerobes that thrive in high-pH $(>8.5)$ and high-salt conditions $\left(>35 \mathrm{~g} \mathrm{l}^{-1}\right)$ is very limited.

In these extreme environments, microorganisms adapted physiological mechanisms to cope with high $\mathrm{pH}$ and salinity. The high salinity of the environment must be compensated to prevent osmotic stress and water leakage from the cell. To cope with high salinity, microorganisms accumulate inorganic or organic compounds that work as osmoregulators, preventing the loss of water inside the cell (Dektova and Boltyanska 2007). The high $\mathrm{pH}$, on the other hand, affects the proton balance and transport by the ATPases that are responsible for ATP production. Even though the $\mathrm{pH}$ of the environment is alkaline, the cell inside usually operates close to neutral $\mathrm{pH}$. Cells cope with this by having more negatively charged cell walls that generate a layer of more concentrated protons, lower $\mathrm{pH}$, near the cell while repelling anions. These adaptations to alkaline conditions have already been recently reviewed in more detail (Banciu and Muntyan 2015; Preiss et al. 2015).

Various haloalkaline environments, like soda lakes, soda solonchak soil, mining industry waste and leafs of salt 
secreting trees, have been described (Qvit-Raz et al. 2008; Sorokin et al. 2008; Sorokin et al. 2014; 2015a; Santini et al. 2015). However, only soda lakes and soda solonchak soils have the buffer capacity to maintain a high $\mathrm{pH}(>8.5)$ and high salinity $\left(>35 \mathrm{~g}^{-1}\right.$ ). Soda solonchak soils have a higher aeration when compared to soda lakes and favour aerotolerant microorganisms (Sorokin et al. 2008). Thus, soda lakes are the most suitable habitats to find anaerobic haloalkaliphilic microorganisms. In these lakes, a high $\mathrm{pH}$ and salinity is caused by the evaporative concentration of soluble sodium carbonates as a result of low concentrations of divalent cations such as calcium or magnesium in the ground waters and surrounding minerals. The extremely high $\mathrm{pH}$ (between 9 and 11) is stable due to a high alkaline buffering capacity of soluble carbonates and salinity can go from $35 \mathrm{~g} \mathrm{l}^{-1}$ up to saturation. Soda lakes harbour highly active and diverse microbial communities involved in the carbon, sulfur and nitrogen cycles. Microbiological studies on soda lakes have been reviewed by Sorokin et al. (2014; 2015a) Also, reviews on application of haloalkaliphilic microorganisms on nitrogen cycle, sulfide oxidation, heavy metals removal, biofuel production and enzyme production are available (Horikoshi 1999; Zhao et al 2014).

In this mini-review, research focused on potential application of anaerobic haloalkaliphilic microorganisms in fermentation of lignocellulosic feedstocks, methane production and sulfur removal technology will be reviewed. The advantages of low VFAs and sulfide toxicity and high methane content will be discussed. We will also focus on the main technological challenges, such as ammonia toxicity and lack of microbial aggregation.

\section{Anaerobic digestion of lignocellulosic feedstocks}

The rate of hydrolysis of sugar polymers is crucial in the fermentation of lignocellulosic feedstocks by anaerobic fermentative bacteria. These feedstocks include waste from agriculture, forest and paper industry where the hydrolytic step is a bottleneck. This is mainly due to the highly packed crystal structure of the fibres composed of lignin, cellulose and hemicellulose (Mathews et al. 2015). To improve hydrolysis, an alkaline pre-treatment can be performed to reduce the fibre crystallinity, making them more accessible to attack of microbial hydrolases (Hendriks and Zeeman 2009).

\section{Fermentation}

After alkaline pre-treatment, the current approach is biofermentation at neutral $\mathrm{pH}$ after neutralizing the alkaline broth. However, the use of haloalkaliphilic microorganisms eliminates the need for $\mathrm{pH}$ adjustments, thus reducing costs
(Porsch et al. 2015). The information on haloalkaliphilic cellulolytic anaerobes is, so far, limited to a few soda lake alkaliphiles. Clostridium alkalicellulosi (Table 1) (Zhilina et al. 2005; Zvereva et al. 2006) is able to produce acetate, ethanol, lactate, hydrogen and traces of formate as products during fermentation of cellulose and cellobiose. Pikuta et al (2006) reported that Anaerovirgula multivorans can weakly grow on cellulose in alkaline medium supplemented with yeast extract. However, no growth kinetics and activity data have been provided. The sugars released from the lignocellulosic feedstocks during alkaline pre-treatment can be used by many cultured haloalkaliphilic saccharolytic fermenters. Such bacteria, belonging to the genera Spirochaeta,Amphibacillus, Alkaliflexus and Alkalitalea, were isolated from different soda lakes and are capable of fermenting cellobiose and glucose, the main product of cellulose hydrolysis (Table 1) (Zhilina et al. 2001; Zhilina et al. 2004; Pikuta et al. 2009; Zhao and Chen 2012). The fermentation products varied between species but are mainly acetate, ethanol, lactate and hydrogen. However, Halanaerobium hydrogeniformans produced acetate, formate and hydrogen as main products in a haloalkaline fed-batch bioreactor fed with hydrolysed switchgrass (Table 1) (Begemann et al. 2012). Ethanol, lactate and hydrogen can be used by haloalkaliphilic acetogens, such as Natroniella and Fuchsiella, converting them to acetate (Table 1) (Zhilina et al. 2012).

\section{Methane production}

Methanogenic fermentation of wastes at haloalkaline conditions can be an interesting option for renewable biogas production. At high $\mathrm{pH}$, VFA toxicity is reduced because VFA are mostly present in the dissociated form which cannot easily cross cell membranes and disrupt the proton balance (Fig. 1). This would allow the operation of such bioreactors at higher organic loadings. At high $\mathrm{pH}$, the $\mathrm{CO}_{2}$ is more retained as carbonates which could lead to a lower $\mathrm{CO}_{2}$ content in the biogas. Also, sulfide at high $\mathrm{pH}$ is mainly in the ionized form $\left(\mathrm{HS}^{-}\right)$which is less volatile and toxic, resulting in a gas with very low concentrations of sulfide. A recent study on the digestion of the microalgae Spirulina at haloalkaline conditions resulted in a biogas with a methane content of $96 \%$ and without traces of sulfide (Nolla-Ardèvol et al 2015). This might reduce the need for biogas posttreatment to remove $\mathrm{CO}_{2}$ and $\mathrm{H}_{2} \mathrm{~S}$, allowing the use of the biogas directly in natural gas supply grid.

In soda lakes, the methanogenic activity in the sediments is similar to freshwater lakes and marine sediments (Kuivila et al. 1989;1990; Sorokin et al. 2015b). Just a few methanogenic archaea have been isolated from soda lakes (Zhilina et al. 2013; Sorokin et al. 2015b). The isolated hydrogenotrophic methanogens belong to the genus 
Table 1 Relevant haloalkaliphilic microorganisms for fermentation of lignocellulosic feedstocks at haloalkaline conditions and their role, optimum $\mathrm{pH}$ and optimum salinity

\begin{tabular}{|c|c|c|c|c|}
\hline Microorganism & Metabolic type & Optimum pH & Optimum salinity $\left(\mathrm{M} \mathrm{Na}^{+}\right)$ & Reference \\
\hline Clostridium alkalicellum & Cellulolytic/fermenter & 9 & $0.15-0.3$ & Zhilina et al. 2005 \\
\hline Anaerovirgula multivorans & Cellulolytic $/$ /fermenter & 8.5 & $0.17-0.34$ & Pikuta et al. 2006 \\
\hline Spirochaeta alkalica & Fermenter & $8.7-9.6$ & $0.5-1.7$ & Pikuta et al. 2009 \\
\hline Spirochaeta aficana & Fermenter & $8.8-9.75$ & $0.85-1.2$ & Pikuta et al. 2009 \\
\hline Spirochaeta asiatica & Fermenter & $8.4-9.4$ & $0.5-1$ & Pikuta et al. 2009 \\
\hline Amphibacillus tropicus & Fermenter & $9.5-9.7$ & $0.17-3.6$ & Zhilina et al. 2001 \\
\hline Amphibacillus fermentum & Fermenter & $8-9.5$ & 1.87 & Zhilina et al. 2001 \\
\hline Alkaliflexus imshenetskii & Fermenter & 8.5 & 0.35 & Zhilina et al. 2004 \\
\hline Alkalitalea saponilacus & Fermenter & 9.7 & $0.44-0.69$ & Zhao and Chen 2012 \\
\hline Halanaerobium hydrogeniformans & Fermenter & 11 & 1.3 & Begemann et al. 2012 \\
\hline Natroniella acetigena & Acetogen & $9.7-10$ & $2.1-2.7$ & Zhilina et al. 2012 \\
\hline Fuchsiella alkaliacetigena & Acetogen & $8.8-9.3$ & $2.8-3.3$ & Zhilina et al. 2012 \\
\hline
\end{tabular}

${ }^{a}$ More information is required to clearly prove that Anaerovirgula multivorans is capable of growing on cellulose

Methanocalculus that use $\mathrm{H}_{2}$ and formate. The isolated methylotrophic methanogens belong to the genera Methanolobus and Methanosalsum that use various methylated compounds. Acetate conversion to methane is also possible, albeit at very low rates, either directly at moderate salinity by alkaliphilic Methanosaeta or by syntrophic associations of reversed acetogens and lithotrophic Methanocalculus at moderate to high salinity (Sorokin et al., 2015b).

\section{Sulfidogenesis}

Bioreduction of inorganic sulfur compounds can be applied to treat sulfur-rich waste streams with high $\mathrm{pH}$ and salinity originated from the oil, natural gas and mining industries. When such streams are exposed to oxygen, mainly oxidized compounds exist like sulfate, thiosulfate, sulfite or sulfur. However in the environment, such compounds might be reduced,

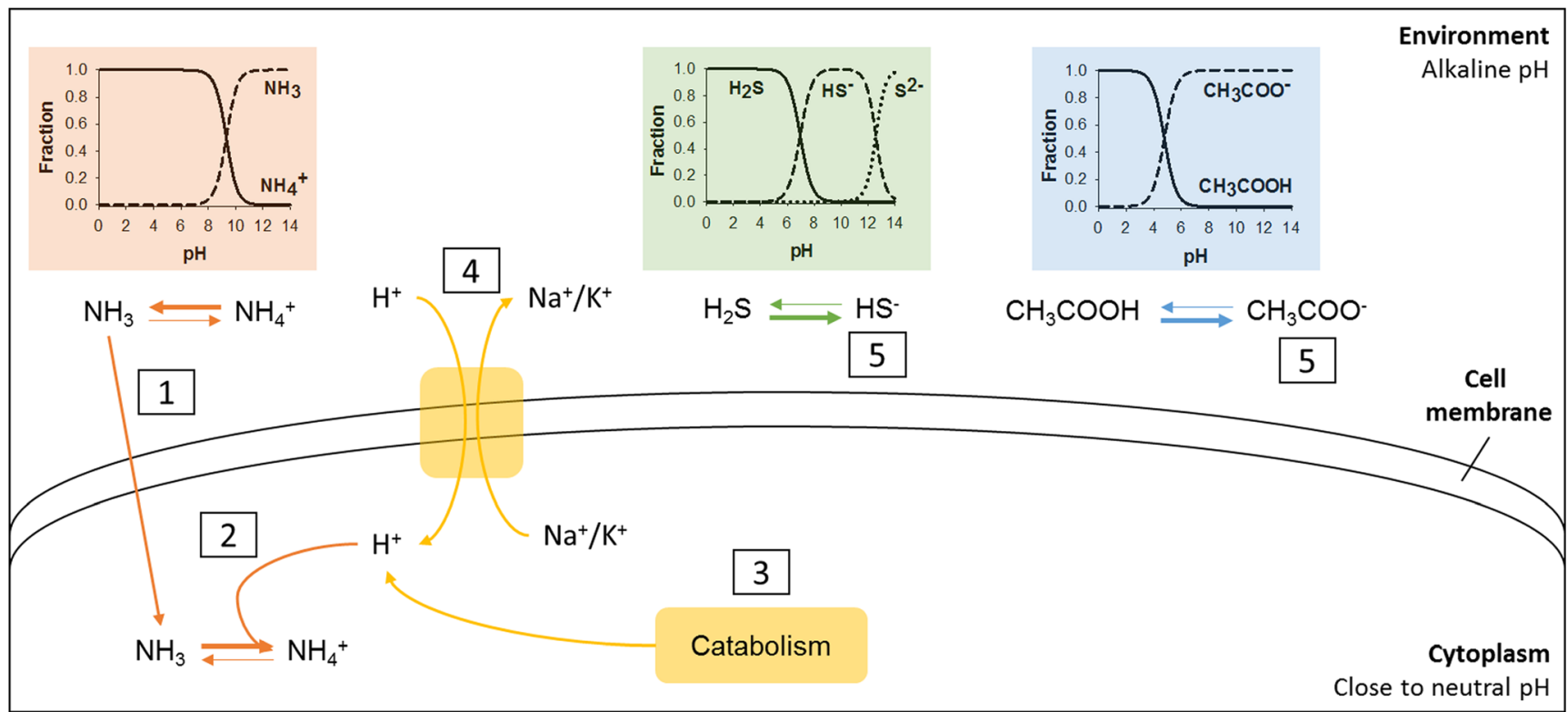

Fig. 1 Effect of ammonia, sulfide and acetate (representing VFAs in general) on microorganisms living at alkaline $\mathrm{pH}$ and chemical equilibrium of ammonia sulfide and acetate at different $\mathrm{pH}$ values. $1-$ at alkaline $\mathrm{pH}$, ammonia tends to the un-ionized species $\left(\mathrm{NH}_{3}\right)$ which can cross cell membranes in contrast with the ionized species $\left(\mathrm{NH}_{4}^{+}\right) ; 2$ - due to the close to neutral $\mathrm{pH}$ inside the cell, the chemical equilibrium shifts towards the $\mathrm{NH}_{4}^{+}$species, consuming one proton $\left(\mathrm{H}^{+}\right)$and disrupting the proton balance; 3 - to compensate the lost $\mathrm{H}^{+}$, the primary source of $\mathrm{H}^{+}$is from the catabolic reactions; 4-also, antiporters in the cell membrane may pump $\mathrm{H}^{+}$in and simultaneously pump sodium $\left(\mathrm{Na}^{+}\right)$or potassium $\left(\mathrm{K}^{+}\right)$out, generating an osmotic difference that needs to be compensated; 5 - at alkaline $\mathrm{pH}$, sulfide and acetate exist in the ionized form, $\mathrm{HS}^{-}$and $\mathrm{CH}_{3} \mathrm{COO}^{-}$, which cannot easily pass the cell membrane 
producing sulfide which is toxic and characterized by the rotten egg smell. To prevent this, the sulfur compounds can be removed from such streams by microbial processes. Oxidized sulfur compounds can be reduced to sulfide in a controlled environment, like a bioreactor. The sulfide produced can be biologically oxidized at oxygen-limited conditions to elemental sulfur, which has economic value (Janssen et al. 2009). Sulfur cycle-related haloalkaliphilic bacteria can be found in soda lakes where the microbial sulfur cycle is very active (Sorokin et al. 2011). Haloalkaliphilic sulfate-reducing bacteria (SRB) that use besides sulfate also thiosulfate and sulfite as electron acceptor and often can disproportionate thiosulfate and sulfite have also been isolated from soda lakes. Both lithotrophic and organotrophic SRB have been described and reviewed by Sorokin et al $(2011 ; 2014 ; 2015 a)$. Elemental sulfur was never shown to be reduced by haloalkaliphilic SRB. However, the specialized sulfur-reducing bacteria, which can reduce or disproportionate elemental sulfur, are also present in these environments (Sorokin et al. 2014; 2015a).

Sulfate reduction at haloalkaline conditions was tested in anaerobic filters and gas lift bioreactors using various electron donors (Zhou and Xing 2015; Sousa et al. 2015). These results revealed that the most reliable electron donors are formate, hydrogen and ethanol (Table 2). The dominant SRB found in these bioreactors belonged to the lithotrophic genera Desulfonatronospira and Desulfonatronovibrio. As produced sulfide at high $\mathrm{pH}$ is present in the dissociated form $\left(\mathrm{HS}^{-}\right)$, this has a much lower toxicity to the biomass compared to neutral $\mathrm{pH}$ (Fig. 1). Sousa et al (2015) showed that sulfate reduction occurred up to $260 \mathrm{mM}$ of sulfide at $\mathrm{pH} 9$, while at $\mathrm{pH} 7$ the sulfide toxicity was already severe at $30 \mathrm{mM}$ (Van Houten et al. 1994). Therefore, bioreactors operated at haloalkaline conditions can handle more concentrated sulfur streams than at neutral $\mathrm{pH}$.

\section{Future challenges for haloalkaline bioreactor research}

The application of anaerobic haloalkaline microbial communities has numerous advantages. But even though these microorganisms are highly adapted to these extreme conditions, there are challenges to overcome before applying such technologies at full scale.

\section{Ammonia toxicity}

One challenge is the ammonia toxicity at high $\mathrm{pH}$ (Fig. 1). At haloalkaline conditions un-ionized ammonia $\left(\mathrm{NH}_{3}\right)$ rather than ammonium $\left(\mathrm{NH}_{4}^{+}\right)$is the dominant chemical species, as the $\mathrm{pKa}$ is $9.25 . \mathrm{NH}_{3}$ can freely diffuse through the cell membrane and disrupt the proton balance inside the cells, making it toxic while $\mathrm{NH}_{4}^{+}$cannot cross the membrane and, therefore, is not toxic (Kayhanian 1999). After crossing the membrane, $\mathrm{NH}_{3}$ is protonized into $\mathrm{NH}_{4}{ }^{+}$due to the near neutral $\mathrm{pH}$ in the cytoplasm maintained by alkaliphiles which, in turn, may weaken its neutral buffering. To compensate this, haloalkaliphiles primarily use protons from the catabolic reactions or can also use antiporters to transport protons into the cell while transporting potassium or sodium out of the cells (Kayhanian 1999). This use of antiporters, however, would generate additional osmotic stress that needs to be compensated.
Table 2 Comparison of different studies on sulfate reduction in bioreactors operated at haloalkaline conditions

\begin{tabular}{|c|c|c|c|}
\hline Reference & Sousa et al. 2015 & Zhou and Xing 2015 & Zhou and Xing 2015 \\
\hline Reactor type & $\begin{array}{l}\text { Gas lift with three-phase } \\
\text { separator }\end{array}$ & Anaerobic filter & Anaerobic filter \\
\hline $\mathrm{e}^{-}$acceptor & Sulfate & Sulfate & Sulfate \\
\hline $\mathrm{e}^{-}$donor & $\mathrm{H}_{2}$ & Formate & Ethanol \\
\hline $\mathrm{pH}$ & 9 & 9.5 & 9.5 \\
\hline $\mathrm{Na}^{+}$conc. $(\mathrm{M})$ & 1.5 & 1 & 1 \\
\hline Temperature $\left({ }^{\circ} \mathrm{C}\right)$ & 35 & 37 & 37 \\
\hline HRT (day) & 3.3 & 1 & 1 \\
\hline $\begin{array}{l}\text { Conversion rates } \\
\qquad\left(\mathrm{mmol} \mathrm{l}^{-1} \text { day }^{-1}\right)\end{array}$ & 18 & 85 & 89.5 \\
\hline Max. sulfide conc. $\left(\mathrm{mmol} \mathrm{l}^{-1}\right)$ & 260 & 76 & 82 \\
\hline Side products & Formate & Acetate & Acetate/formate/lactate \\
\hline Biomass conc. $\left(\mathrm{mg} \mathrm{1}^{-1}\right)$ & $7.2( \pm 3)$ & N.D. & N.D. \\
\hline Biomass aggregation & No aggregation & N.D. & N.D. \\
\hline
\end{tabular}

N.D. not described 


\section{Lack of aggregation}

The high $\mathrm{pH}$ and salinity in bioreactors can prevent a stable aggregation of microorganisms which is usually essential for biomass retention of slowly growing organisms. Previous studies showed that aggregation in bioreactors at high $\mathrm{pH}$ and salt concentrations did not occur at all or that stable granules disintegrated in high salinity bioreactors (Ismail et al. 2008; Sousa et al. 2015). The causes for this are still in discussion, and different mechanisms are proposed. At high $\mathrm{pH}$, the hydrophobicity of cell surfaces and extracellular polymeric substance (EPS) might change and hydrophobicity has been reported to affect the microbial attachment (van Loosdrecht et al. 1987; Otto et al. 1999). Another possibility was proposed by Ismail et al (2008) who suggested that at high $\mathrm{Na}^{+}$ concentrations, $\mathrm{Na}^{+}$replaces divalent cations, such as $\mathrm{Ca}^{2+}$, in the EPS matrix of aggregates, making the aggregates less stable. Another possible effect could be downregulation of carbon metabolism at high salinities as reported by $\mathrm{He}$ et al (2010). This subsequently lowers the EPS production in favour of osmolites production to balance the high salinity. Yet, halophilic isolates from the Halomonas genus were shown to produce EPS, and this could point to a significant role of high $\mathrm{pH}$ in the lack of aggregation at haloalkaline conditions (Martínez-Cánovas et al. 2004). To overcome the challenge of no aggregation at haloalkaline conditions, technologies like use of a biofilm support material in the reactor or a membrane biological reactor (MBR) should be considered.

\section{Operational challenges}

Additional factors related to the engineering of haloalkaline bioreactors need to be addressed. By operating bioreactors at high salt and high $\mathrm{pH}$, there is an increased risk of scaling if divalent cations are added. This problem requires special attention when designing and optimizing the processes. Also, the high $\mathrm{pH}$ and salinity effluent might require additional treatment to neutralize $\mathrm{pH}$ and salinity prior to its discharge.

\section{Conclusions and future prospects}

Application of haloalkaliphilic anaerobic microbial communities in the abovementioned processes is an interesting route to consider in specific cases and/or to increase their efficiency. Operation at haloalkaline conditions has several advantages, like low VFA and sulfide toxicity, production of low $\mathrm{CO}_{2}$ containing and $\mathrm{H}_{2} \mathrm{~S}$-containing biogas and reduced need for $\mathrm{pH}$ control. On the other hand, the challenges of ammonia toxicity and lack of biomass aggregation need to be overcome for application in an industry. In general, more laboratory-scale bioreactor studies focusing on these microorganisms are required. Information on reaction rates, biomass growth and microbial communities during longterm experiments in bioreactors is essential to scale up these technologies.

Aknowledgments This work was performed in the TTIWcooperation framework of Wetsus, European Centre of Excellence for Sustainable Water Technology (www.wetsus.nl). Wetsus is funded by the Dutch Ministry of Economic Affairs, the European Union Regional Development Fund, the Province of Fryslân, the City of Leeuwarden and the EZ/ Kompas program of the "Samenwerkingsverband Noord-Nederland". The authors would like to thank the participants of the research theme "Sulfur", namely Paqell, for fruitful discussions and financial support.

Conflict of interest The authors declare that they have no competing interests.

Open Access This article is distributed under the terms of the Creative Commons Attribution 4.0 International License (http:// creativecommons.org/licenses/by/4.0/), which permits unrestricted use, distribution, and reproduction in any medium, provided you give appropriate credit to the original author(s) and the source, provide a link to the Creative Commons license, and indicate if changes were made.

\section{References}

Banciu HL, Muntyan MS (2015) Adaptive strategies in the doubleextremophilic prokaryotes inhabiting soda lakes. Curr Opin Microbiol 25:73-79

Begemann MB, Mormile MR, Sitton OC, Wall JD, Elias DA (2012) A streamlined strategy for biohydrogen production with Halanaerobium hydrogeniformans, an alkaliphilic bacterium. Front Microbiol 3:1-12

Dektova EN, Boltyanskaya YV (2007) Osmoadaptation of haloalkaliphilic bacteria: role of osmoregulators and their possible practical application. Microbiol 76:511-522

He Z, Zhou A, Baidoo E, He Q, Joachimiak MP, Benke P, Phan R, Mukhopadhyay A, Hemme CL, Huang K, Alm EJ, Fields MW, Wall J, Stahl D, Hazen TC, Keasling JD, Arkin AP, Zhou J (2010) Global transcriptional, physiological, and metabolite analyses of the response of Desulfovibrio vulgaris Hildenborough to salt adaptation. Appl Environ Microbiol 76:1574-1586

Hendriks ATWM, Zeeman G (2009) Pretreatments to enhance the digestibility of lignocellulosic biomass. Bioresour Technol 100:10-18

Horikoshi K (1999) Alkaliphiles: some applications of their products for biotechnology. Microbiol Mol Biol 63:735-750

Ismail SB, Gonzalez P, Jeison D, van Lier JB (2008) Effects of high salinity wastewater on methanogenic sludge bed systems. Water Sci Technol 58:1963-1970

Janssen AJH, Lens P, Stams AJM, Plugge CM, Sorokin DY, Muyzer G, Dijkman H, van Zessen E, Luimes P, Buisman CJN (2009) Application of bacteria involved in the biological sulfur cycle for paper mill effluent purification. Sci Total Environ 407:1333-1343

Kayhanian M (1999) Ammonia inhibition in high-solids biogasification: an overview and practical solutions. Environ Technol 20:355-365

Kuivila KM, Murray JW, Devol AH (1990) Methane production in the sulfate-depleted sediments of two marine basins. Geochim Cosmochim Acta 54:403-411 
Kuivila KM, Murray JW, Devol AH, Novelli PC (1989) Methane production, sulfate reduction and competition for substrates in the sediments of Lake Washington. Geochim Cosmochim Acta 53:409416

Martínez-Cánovas MJ, Quesada E, Martínez-Checa F, Béjar V (2004) A taxonomic study to establish the relationship between exopolysaccharide-producing bacterial strains living in diverse hypersaline habitats. Curr Microbiol 48:348-353

Mathews SL, Pawlak J, Grunden AM (2015) Bacterial biodegradation and bioconversion of industrial lignocellulosic streams. Appl Microbiol Biotechnol 2939-2954

Nolla-Ardèvol V, Strous M, Tegetmeyer HE (2015) Anaerobic digestion of the microalga Spirulina at extreme alkaline conditions: biogas production, metagenome, and metatranscriptome. Front Microbiol 6:1-21

Otto K, Elwing H, Hermansson M (1999) Effect of ionic strength on initial interactions of Escherichia coli with surfaces, studied online by a novel quartz crystal microbalance technique. J Bacteriol 181:5210-5218

Pikuta EV, Takashi I, Krader P, Tang J, Whitman WB, Hoover RB (2006) Anaerovirgula multivorans gen. nov., sp. nov., a novel sporeforming, alkaliphilic anaerobe isolated from Owens lake, California, USA. Int J Syst Evol Microbiol 56:2623-2629

Pikuta EV, Hoover RB, Bej AK, Marsic D, Whitman WB, Krader P (2009) Spirochaeta dissipatitropha sp. nov., an alkaliphilic, obligately anaerobic bacterium, and emended description of the genus Spirochaeta Ehrenberg 1835. Int J Syst Evol Microbiol 59:17981804

Porsch K, Wirth B, Tóth EM, Schattenberg F, Nikolausz M (2015) Characterization of wheat straw-degrading anaerobic alkalitolerant mixed cultures from soda lake sediments by molecular and cultivation techniques. Microb Biotechnol. doi:10.1111/17517915.12272

Preiss L, Hicks DB, Suzuki S, Meier T, Krulwich TA (2015) Alkaliphilic bacteria with impact on industrial applications, concepts of early life forms, and bioenergetics of ATP synthesis. Front Bioeng Biotechnol 3:1-16

Qvit-Raz N, Jurkevitch E, Belkin S (2008) Drop-size soda lakes: transient microbial habitats on a salt-secreting desert tree. Genetics 178 : $1615-1622$

Santini TC, Warren LA, Kendra KE (2015) Microbial diversity in engineered haloalkaline evironments shaped by shared geochemical drivers observed in natural analogues. Appl Environ Microbiol 81: 5026-5036

Sorokin ID, Kravchenko IK, Doroshenko EV, Boulygina ES, Zadorina EV, Tourova TP, Sorokin DY (2008) Haloalkaliphilic diazotrophs in soda solonchak soils. FEMS Microbiol Ecol 65:452-433

Sorokin DY, Kuenen JG, Muyzer G (2011) The microbial sulfur cycle at extremely haloalkaline conditions of soda lakes. Front Microbiol 2: $1-16$
Sorokin DY, Berben T, Melton ED, Overmars L, Vavourakis CD, Muyzer G (2014) Microbial diversity and biogeochemical cycling in soda lakes. Extremophiles 18:791-809

Sorokin DY, Banciu HL, Muyzer G (2015a) Functional microbiology of soda lakes. Curr Opinions Microbiol 25:88-96

Sorokin DY, Abbas B, Geleijnse M, Pimenov NV, Sukhacheva MV, van Loosdrecht MCM (2015b) Methanogenesis at extremely haloalkaline conditions in the soda lakes of kulunda steppe (Altai, Russia). FEMS Microbiol Ecol 91:1-12

Sousa JAB, Plugge CM, Stams AJM, Bijmans MFM (2015) Sulfate reduction in a hydrogen fed bioreactor operated at haloalkaline conditions. Water Res 68:67-76

Van Houten RT, Hulshoff Pol LW, Lettinga G (1994) Biological sulphate reduction using gas-lift reactors fed with hydrogen and carbon dioxide as energy and carbon source. Biotechnol Bioeng 44:586-594

Van Loosdrecht MCM, Lyklema J, Norde W, Schraa G, Zehnder AJB (1987) The role of bacterial cell wall hydrophobicity in adhesion. Appl Environ Microbiol 53:1893-1897

Zhao B, Chen S (2012) Alkalitalea saponilacus gen. nov., sp. nov., an obligately anaerobic, alkaliphilic, xylanolytic bacterium from a meromictic soda lake. Int J Syst Evol Microbiol 62:2618-2623

Zhao B, Yan Y, Chen S (2014) How could haloalkaliphilic microorganisms contribute to biotechnology? Can J Microbiol 60:717-727

Zhilina TN, Garnova ES, Turova TP, Kostrikina NA, Zavarzin GA (2001) Amphibacillus fermentum sp. nov., Amphibacillus tropicus sp. nov.new alkaliphilic, facultatively anaerobic, saccharolytic Bacilli from lake magadi. Microbiology 70:825-837

Zhilina TN, Appel R, Probian C, Brossa EL, Harder J, Widdel F, Zavarzin GA (2004) Alkaliflexus imshenetskii gen. nov. sp. nov., a new alkaliphilic gliding carbohydrate-fermenting bacterium with propionate formation from a soda lake. Arch Microbiol 182:244-253

Zhilina TN, Kevbrin VV, Tourova TP, Lysenko AM, Kostrikina NA, Zavarzin GA (2005) Clostridium alkalicellum sp. nov., an obligately alkaliphilic cellulolytic bacterium from a soda lake in the Baikal region. Microbiology 74:557-566

Zhilina TN, Zavarzina DG, Kevbrin VV, Kolganova TV (2013) Methanocalculus natronophilus sp. nov., a new alkaliphilic hydrogenotrophic methanogenic archaeon from a soda lake, and proposal of the new family Methanocalculaceae. Microbiology 82:698-706

Zhilina TN, Zavarzina DG, Panteleeva AN, Osipov GA, Kostrikina NA, Tourova TP, Zavarzin GA (2012) Fuchsiella alkaliacetigena gen. nov., sp. nov., an alkaliphilic, lithoautotrophic homoacetogen from a soda lake. Int J Syst Evol Microbiol 62:1666-1673

Zhou J, Xing J (2015) Effect of electron donors on the performance of haloalkaliphilic sulfate-reducing bioreactors for flue gas treatment and microbial degradation patterns related to sulfate reduction of different electron donors. Biochem Eng J 96:14-22

Zvereva EA, Fedorova TV, Kevbrin VV, Zhilina TN, Rabinovich ML (2006) Cellulase activity of a haloalkaliphilic anaerobic bacterium, strain Z-7026. Extremophiles 10:53-60 